\title{
Ethnic ties, location choice, and firm performance in foreign direct investment: A study of Taiwanese business groups FDI in China
}

\author{
Ruey-Jer Bryan Jean ${ }^{\mathrm{a}, *}$, Danchi Tan ${ }^{\mathrm{a}}$, Rudolf R. Sinkovics ${ }^{\mathrm{b}, 1}$ \\ ${ }^{a}$ National Chengchi University, 64, Sec. 2 Zhi-Nan Road, Taipei 11605, Taiwan \\ ${ }^{\mathrm{b}}$ The University of Manchester, Manchester Business School Booth Street West, Manchester M15 6PB, United Kingdom
}

\section{A R T I C L E I N F O}

\section{Keywords:}

China

Ethnic

FDI

Market entry

Social ties

\begin{abstract}
A B S T R A C T
This paper examines ethnic ties and their impact on FDI location choice and firm performance. Drawing on social network theory and using data from 88 Taiwanese business groups, the study tests the impact of ethnic ties on firm FDI location choice and performance outcomes in China. Results show that ethnic ties of top managers matter in facilitating firm FDI location choice. In contrast to our expectations however, ethnic ties do not help to improve firm performance in China. Implications of these results are discussed in view of existing literature and future research opportunities are delineated.
\end{abstract}

(c) 2011 Published by Elsevier Ltd.

\section{Introduction}

The growth in foreign direct investment (FDI) has resulted in a vast literature examining the location decision, entry modes and performance implications of firms venturing abroad. Various theoretical lenses, including transaction cost theory (TCE) (Williamson, 1975), resource based view (RBV) (Barney, 1991) and organizational learning theory (Ruigrok \& Wagner, 2003) have been applied to these streams of research and advanced the understanding of FDI strategic behaviors and performance, either in developed or emerging countries. Recently, researchers have tried to adopt a network approach to examine firm internationalization (e.g., Ghauri, Lutz, \& Tesfom, 2003; Zhou, Wu, \& Luo, 2007). However, most of these studies focus on business networks and linkages such as alliances and joint ventures (e.g., Lu \& Beamish, 2001). Ethnic ties, which refer to informal social or personal networks encompassing characteristics such as shared mother tongue, national origins, ethnic group and region of birth (Zaheer, Lamin, \& Subramani, 2009), have been largely ignored in the international business literature. Past studies have corroborated the hypothesis asserting that family ties and co-ethnic bonds are instrumental in the growth of ethnic enterprises (Cobas \& DeOllos, 1989). Hence, managerial and personal ties may play a crucial role for firm strategic decision making and performance. For example, Luo and Chung (2005) examine the role of specific relationships including family and prior personal contacts and find that these ties can facilitate business groups' performance. Prior research also points at the importance of the circumstances to what extent these personal ties matter (Peng \& Luo, 2000). This is because too strong ties and contacts may hinder creativity and thus be detrimental to firm strategies and performance (Burt, 1997). As such, extant literature has offered only limited or contradictory evidence on the role of ethnic ties on firm strategic decisions and performance outcome, especially in the international context.

In order to overcome these limitations of extant literature on the role of ethnic ties in international business, the purpose of this study is to examine the impact of ethnic ties on firm foreign market entry and performance implications. We focus on

\footnotetext{
* Corresponding author.

E-mail addresses: bryan@nccu.edu.tw (R.-J. Jean), dctan@nccu.edu.tw (D. Tan), Rudolf.Sinkovics@manchester.ac.uk (R.R. Sinkovics). URL: http://www.personal.mbs.ac.uk/rsinkovics/

${ }^{1}$ Tel.: +441613068980.
} 
particular strategic choices, i.e., foreign location decision. Location choice has been identified as a central theme in the domain of international business (Dunning, 1998). However, the association between ethnic ties and firm location choice has to date received a limited consideration in the extant literature. One exception is the recent work by Zaheer et al. (2009)\{2009 \#2138\}, who find that ethnic networks exert greater influence than cluster capabilities on location decisions in the services offshoring to India. We extend their work by examining firm location choice in entering China. China has attracted a great deal of FDI in recent years. It has been argued that social networks such as "Guanxi" and personal contacts played a crucial role in doing business in China (Buckley, Clegg, \& Tan, 2006; Lee, Pae, \& Wong, 2001) due to lack of sufficient institutional support in emerging markets (Park \& Luo, 2001). In addition, our research examines the conditions under which ethnic ties can enhance firm FDI performance in China. We examine the influence of ethnic ties on firm performance under different levels of firm technological capabilities (R\&D intensity). Prior research on multinationality and performance contends that firm specific assets such as technological capabilities are associated with greater firm international performance (Casson, 1985; Hennart, 2009). However, social capital theory argues that strong social ties may inhibit firm innovative capabilities (Burt, 1997). Accordingly, this study tries to examine whether higher level of firm technological capability would complement or substitute the strength of ethnic ties on firm FDI performance in China.

We specifically focus on Taiwanese business groups' FDI strategy in China as our empirical setting for the following reasons: first, people from China and Taiwan share a common language and heritage. Historically, the middle and south coast provinces of China are the ancestral home for many thousands who fled China for Taiwan after the establishment of People's Republic in 1949 (Filatotchev, Strange, Piesse, \& Lien, 2007). Many of them rebuilt their businesses in Taiwan, but the ethnic and family links with China persist. The Taiwanese ethnicity has been divided into two groups: mainlanders and islanders. Mainlanders refer to people who moved to Taiwan from mainland China in the years since 1949, after World War II. Islanders are those who have been native Taiwanese for many generations (Tan \& Yu, 2000). Mainlanders typically have stronger ethnic ties with Mainland China than islander. Until the present, many mainlanders still speak the same dialects as they or their parents did in China. Mainlanders in Taiwan emigrated from various regions of Mainland China. The largest ethnic groups of mainlanders in Taiwan, "Minnan," are people who come from the South-East coast of Mainland China. Hence, it has been argued that the motivation for Taiwanese firms to locate their FDI investment in China is influenced by strong ethnic ties with the home country (Strange, Filatotchev, Lien, \& Piesse, 2009). This can be more salient for business groups because prior research shows that Taiwanese business groups are characterized by family and social networks (Chang, Chung, \& Mahmood, 2006). The second reason why Taiwanese FDI in China is an interesting setting for this study is that compared to their Western competitors, most Taiwanese firms have weaker firm-specific capabilities such as technological and marketing capabilities and thus it is more challenging for them to compete overseas on the basis of these firm-specific capabilities. Business networks and social ties have been identified as key drivers for Taiwanese outward FDI (Chen \& Chen, 1998). In contrast to traditional FDI theory which contends that firms engaging in FDI must be equipped with strong specific advantages, Taiwanese FDI in China provide good opportunities to examine how weaker firms gain competitive advantages in their internationalization strategies in an emerging market.

This study contributes to existing knowledge in three ways. First, while prior studies have examined network linkages and their relationships with firm FDI strategies, most studies focus on business networks and relationships \{e.g., Chen \& Chen, 1998 \#2228; Ghauri et al., 2003 \#2230\}. Managerial ties of ethnic links and their associations with firm FDI have been largely neglected. Accordingly, drawing from social network theory (Burt, 1997), this study extends network theory perspectives on internationalization to the interpersonal and ethnic ties level, by examining how the ties affect FDI location and performance. Second, prior studies examining relationships between different managerial ties and firm performance offer inconclusive results (Luo, 2003; Peng \& Luo, 2000). By integrating social network theory with internalization theory in international business, this research explores the conditions under which ethnic ties can play their role for enhancing firm FDI performance (Chang et al., 2006). In this way, this study responds to the call for more research on examining the limitations and boundary of managerial and ethnic ties in firm performance. Third, by using Taiwanese business groups' investment in China as the empirical setting, our study offers additional empirical evidence on the internationalization of MNEs' from newly industrializing countries to the literature. This empirical context also enables us to enrich the understanding of the influence of ethnic ties in an emerging market context, which exhibits incomplete institutional structures and rather weak contractual enforcement. In such a context, informal networks and ethnic ties may be more salient for successful firm FDI strategies and performance.

The article is organized as follows. The literatures on social network theory and ethnic ties are reviewed to provide support for the links between each construct. Predictions regarding the interrelationships between ethnic ties, location choice and firm performance are then proposed. These hypotheses are tested empirically and results are presented. The paper concludes with a discussion of the findings and directions for future research.

\section{Review of the literature and hypotheses}

\subsection{Social network theory}

In this study, we draw on social network theory to analyze the impact of ethnic ties on FDI location choice and performance. Extant literature has used different terms to describe social networks such as social ties, interpersonal relationships, personal connections, and relational networks. Burt (1997) defines social networks as opportunities a player 
receives through relationships with other players such as colleagues. Björkman and Kock (1995) define the social network as the network of individuals who are linked through interactions consisting mainly of social exchanges, but information and business exchanges can also take place through those social relationships. As such, most conceptualizations of social networks include relations or networks of relationships among individuals and organizations.

Extant studies identify social networks as a mechanism for facilitating information exchange and resource flow within and between organizational members. Jones, Hesterly \& Borgatti (1997) argue that social networks can be seen as an effective governance mechanism which creates structural embeddedness in several social mechanisms including restricted access, macro-culture, collection sanctions and reputations. Therefore, it has been argued that social ties can be idiosyncratic to a firm, which in turn, may provide firms with inimitable advantages. Some empirical evidence shows that social networks and ties of top managers can enhance firm performance (Luo, 2003; Peng \& Luo, 2000).

Recently, scholars have applied the social network approach to firm internationalization strategies. The IMP (Industrial Marketing and Purchasing) group argues that interactions among three elements of the network, including resources, actors, and activities, facilitate the degree of firm internationalization (Ford, 2002). In a similar vein, Chen and Chen (1998) consider the effects of network linkages on Taiwanese on FDI location choice. They find that external relation linkages based on personal relationships or business transactions create trust and mutual understanding and facilitate Taiwanese FDI in China and Southeast Asia. Recently, Zhou et al. (2007) emphasized the strategic value of social network in the context of internationalization for helping exchange knowledge of foreign market opportunities, advising and experiential learning about cross-border business operations and referral trust and solidarity. According to this conceptual and empirical work, social network has been identified by prior work to provide strategic value for firm entering foreign market. However, most of these earlier studies focus more on business networks and connections and less attention is placed on interpersonal relationships, ethnic ties and their links with firm strategic decisions and performance implications in the context of firm internationalization.

\subsection{Role of ethnic ties in firm internationalization}

Ethnic ties are specific aspects of social networks which are characterized by personal relationship elements such as mother tongue, national origins, ethnic group and region of birth (Zaheer et al., 2009). In this study, we focus on managerial ethnic ties, defined as top manager's boundary-spanning activities and their associated interactions with external entities based on kinship and community ties (Peng \& Luo, 2000). Managers can cultivate ethnic ties to interact with external entities such as suppliers, customers, competitors and government to develop relationships (Gao, 2003). Ethnicity and race are strong categorical criteria for social networks (Eroglu, Thornton, \& Bellenger, 2005; Stiles \& Galbraith, 2004) and ethnic groups can be identified which place a strong focus on ethnicity and connections (Dana \& Dana, 2007; Ethnic Minority Business Forum, 2008). For example, there are approximately 50 million ethnic Chinese living outside mainland China, particularly in Asia-Pacific countries such as Thailand, Malaysia, Taiwan and Singapore (Gao, 2003). Ethnic Chinese networks are often characterized as building personal connections (Guanxi) based on regional collegiality and kinship. Business transactions, ranging from financing to advance orders to material purchases, are regularly done through personal contact and recommendation by friends. It has been argued that informal connections play a major part in transactions among overseas Chinese business. Hence, within the same ethnic circle, business transactions are easier to achieve on the basis of ethnic links and connections.

Drawing from the social network perspective, ethic ties and connections serve as intermediaries in facilitating exchange of the most valuable information. Although kinship and community ties initially exist as affective ties and social relation, they have the potential to serve economic and instrumental purposes (Burt, 1997). It has been argued that ethnic networks facilitate information sharing that helps match buyers and sellers in the international market. The social embeddedness provided by ethnic ties can reduce the speed and cost of information and resource acquisition (Gao, 2003). Hence, ethic ties have been suggested to help overcome liabilities of foreignness and newness in firm internationalization processes. In addition, according to social network theory, ethnic networks can serve as an effective governance mechanism to build trust between exchange parties which help deters opportunistic behavior such as contract violation through enforcement of community sanctions. This is particularly important when business transactions are conducted in emerging market where contract laws and infrastructures are weak and incomplete (Xin \& Pearce, 1996). Empirical evidence has shown the critical role of managerial and ethnic ties in emerging markets. For example, Peng and Luo (2000) find that managers with strong ties with government in China can enhance firm performance. In addition, in the study of entrepreneurs' FDI location choices, Zaheer et al. (2009) show that managers who have strong ethnic ties with their original hometown prefer to locate their FDI activities in India.

In the context of Taiwanese business groups' FDI decision, we argue that ethnic ties play a crucial role in firm's strategic decisions, particularly in the FDI decision in China because Taiwan and China have strong ethnic links. Prior literature shows that Taiwanese business groups are characterized by strong social networks and relationships in their strategic behaviors. Because of specific ethnic links with China, the internationalization strategies of Taiwanese business groups may be largely influenced by ethnicity. Managers in Taiwanese business groups may choose to locate their FDI more in China in order to gain critical resources through ethnic ties. This special social network based on kinship and regional collegiality may provide firms with an information structure enabling them to function more effectively with their environment. In emerging markets characterized by institutional failure such as in China, the need for using ethnic ties to facilitate information sharing and access resources may be stronger. Prior empirical studies show that relational linkages facilitate Taiwanese FDI in China (Chen \& Chen, 1998; Strange et al., 2009). Hence, 
H1. Firms are more likely to locate their FDI in China where they have stronger managerial ethnic ties.

The role of network ties and their impact on firm performance have been well documented in the extant literature. For example, Xin and Pearce (1996) argued that in China Guanxi can substitute for insufficient formal infrastructure. Luo (2003) notes that personal ties provide flexible resource allocation in an environment where factor mobility is severely constrained and governmental interference remains a factor. Some studies also argued that network ties can serve as an effective mechanism to enhance firm internationalization performance. For example, Lu and Beamish (2001) demonstrate that alliances with local partners provide information benefits for entrepreneurs firms and thus enhance FDI performance. Zhou et al. (2007) noted that Guanxi-related social networks mediate the relationship between outward and inward FDI and firm performance. The complexity of domestic market environment in emerging economies imposes constraints on inward FDI. Exploiting local network ties can help firm develop new capabilities and reduce transaction costs in the internationalization processes, which in turn, can enhance the likelihood of success and survival in FDI in emerging markets. This is consistent with the resource based perspective which argues that social capital in managerial ties can be viewed as a valuable, unique, and intangible resource that is difficult to replicate, thus giving firms a significant advantage. Based on theory and empirical evidence, we argue that managers with stronger ethnic ties in China perform better in their FDI activities. Hence:

H2. Foreign entrants are more likely to perform better in China where they have stronger managerial ethnic ties.

Despite significant benefits provided by ethnic networks, social network theory suggests to identify the limitations and boundaries of network ties (Peng \& Luo, 2000). The relational theory of social networks states that sporadic interactions of weak ties are effective means for gaining novel information and accessing to diverse pools of information source (Granovetter, 1985). The structure theory of social networks also notes that too close ties and networks may cause redundant information and knowledge which are detrimental to identify and develop new ideas and opportunists (Burt, 1997). Accordingly, it is valuable to take a contingent perspective to investigate the impact of ethnic ties on firm strategic choices and performance. The contingent perspective views ethnic networks as a variable action contingent on some expectation of net returns after adjusting for costs incurred in cultivating, developing and marinating such networks. Specifically, we suggest that firms vary in influence of ethnic ties on FDI performance according to their technological capabilities.

Firm technological capabilities embodied in R\&D intensity have been widely related to firm FDI performance in prior international business literature. Internalization theory suggests that firms with stronger R\&D intensity are more likely to achieve higher performance in FDI because internalization of proprietary asset across international borders helps to reduce transaction-related costs and risks (Casson, 1985; Hennart, 2009). Accordingly, firms with strong technological capabilities are more likely to focus on developing and exploiting firm specific assets such as R\&D and information systems to achieve greater returns in FDI. These firms may be more independent and pay less attention to develop their networks strategies such as relying on ethnic ties as a strategic choice (Peng, 2003). In contrast, firms with weaker technological capabilities are more relationship-intensive and rely more on ethnic ties in order to gain external resources such as local market information and knowledge. In addition, R\&D intensive firms generally place more emphasis on information and knowledge and unique combinations thereof. As such, drawing on a social network perspective, ethnics ties based on tight kinship have less chance of obtaining valuable and novel information than firms with stronger technological capabilities which in turn, will result in less performance returns. Empirical studies show that the relationship between knowledge sharing and product innovation between headquarters and subsidiaries is weaker when subsidiaries have strong networks effects (Lee, Chen, Kim, \& Johnson, 2008). Liao \& Welsch's (2003) work indicate that the effect of social capital on growth aspiration is weaker for technologybased nascent entrepreneurs than for the non-technology-based counterparts. Based on these theoretical arguments and previous empirical evidence, we expect that the positive effect of managerial ethnic ties on firm FDI performance is weaker for firm with strong technological capabilities.

H3. The greater the foreign entrant's technological capabilities, the lower the positive effect of managerial ethnic ties on post-entry performance in China.

\section{Method}

This study examines the impact of ethnic ties on FDI location strategy and performance of Taiwanese firms in China. In emerging economies, firms typically grow both domestically and internationally in the form of business groups in order to accommodate institutional peculiarities (Chung, 2001; Khanna \& Palepu, 2000). This also applies to Taiwan, where business groups are major players in the economy and a major contributor to outward FDI (Chung, 2006). Thus, Taiwanese business groups provide a suitable setting for research on the FDI behaviors and performance (e.g., Filatotchev, Strange, Piesse, \& Yung-Chih, 2007).

Our initial sample consists of all 98 Taiwanese business groups featured in both the 1998 and 2002 editions of the directory Business Groups in Taiwan (BGT). This directory has been published since 1972 by the China Credit Information Service (CCIS), the oldest credit-checking agency in Taiwan and an affiliate of Standard \& Poor's. The BGT directory is the most comprehensive source for business groups in Taiwan and is commonly used for scholarly research on examining the behavior and performance of Taiwanese business entities (e.g., Luo \& Chung, 2005; Mahmood \& Mitchell, 2004). It defines a 
business group as "a coherent business organization that includes several independent enterprises" and used multiple criteria to identify firms forming part of a business group ${ }^{2}$. These criteria ensure that member firms of business groups in the directory are directed by common decision-makers, who would oversee the allocation of resources, such as managerial ethnic ties, across the group.

The BGT directory also reports FDI activities of the business groups. Missing values reduced our final sample to 88 business groups with on average 26 member firms. It should be noted that the directory reports data of two previous years. We use data for the year 2000 from the 2002 BGT directory to measure our dependent variables, and four-year lagged values (i.e., 1996 data, from the 1998 directory) for all explanatory and control variables. This approach reduces possible biases arising from reverse causality.

\subsection{Measurement}

\subsubsection{Dependent variables}

Our dependent variables are (1) the tendency of a business group of investing in China and (2) the post-entry performance of a business group in China. We measure a business group's tendency of investing in China by dividing the sales of all Chinese member firms by total group sales. We measure the post-entry performance of a business group in China by its sales growth rate in China over the study period (i.e., the years between 1996 and 2000). Sales growth is a suitable proxy for the post-entry performance of foreign investors because foreign entrants must grow quickly to reach a size at which their operations are cost-competitive with incumbent firms if they are to survive (Porter, 1980; Shane, 1996).

\subsubsection{Explanatory variables}

Our key explanatory variable is managerial ethnic ties that drive the FDI decision of a business group. To measure them requires us to identify managers with key roles affecting the entire business group. The BGT directory generates such a list by asking member firms to identify the core managers who have influence over each member firm within their group. This list of managers is also commonly used by researchers who study managers of Taiwanese business groups (Luo \& Chung, 2005). The directory also provides information regarding the ethnic origins of these core managers, thus enabling us to identify whether the managers are mainlanders or islanders. Since no previously developed scales are available for managerial ethnic ties related to our specific context, we measure managerial ethnic ties by drawing on the business directory information, using the number of core managers who are mainlanders.

Another explanatory variable of our study is technological capability of a group. It is measured by the sales-weighted average of R\&D expenditures as percentage of sales of the member firms, as reported in the Taiwan Economic Journal (TEJ) database (Anand \& Delios, 2002; Tan \& Meyer, 2010).

\subsubsection{Control variables}

We control for the size of the business groups. Larger groups may have more resources to support outward FDI. We measure group size by the logarithm of total employment of the business group (Tan \& Meyer, 2010). We also control for the level of product diversification by including the entropy measure at 1996 (Delios \& Beamish, 1999; Hoskisson, Hitt, Johnson, \& Moesel, 1993). Business groups with higher levels of product diversification may be less likely to conduct international expansion (Bowen \& Wiersema, 2005). We include two industry-level control variables in the analysis. Core industry growth is the sales growth of the core industry of a business group (Tan \& Meyer, 2010). Business groups in fast-growing domestic markets may have low incentives to expand into new markets such as China. Service oriented groups are dummy equal to one if the main industry of a business group belongs to a service industry (Tan \& Meyer, 2010). Some service sectors, such as banking and telecommunication, are subject to greater scrutiny from both home and local governments, and thus may be more conservative in conducting FDI. Finally, for empirical examination of business groups' performance in China, we include the initial level of Chinese sales ratio in 1996 as a control variable.

Table 1 reports summary statistics and correlations for the variables. Although some of the independent variables are significantly correlated at the 0.05 level, the largest variance inflation factors of our empirical models for predicting location choice and performance are 1.27 and 1.3, respectively, and the mean values are 1.21 and 1.2, suggesting that multicollinearity does not threaten the validity of our coefficient estimates.

\section{Analysis and results}

Table 2 presents the empirical result on location choice of business groups. Hypothesis 1 predicts that business groups are more likely to invest in China when they have strong managerial ethnic ties. The coefficient of managerial ethnic ties in Table 2 is positive and significant $(\beta=0.015, p<0.1)$, consistent with this prediction. H1 is supported.

\footnotetext{
${ }^{2}$ A key criterion is that $50 \%$ of the shares of member firms are owned by the same firm(s) or the same individual(s), or that member firms own more than $33 \%$ of the ownership of other member firms. Moreover, $50 \%$ of the shareholders, directors, auditors and decision makers have to be the same for the member firms.
} 
Table 1

Descriptive statistics.

\begin{tabular}{|c|c|c|c|c|c|c|c|c|c|c|}
\hline & Mean & Std. dev & 1 & 2 & 3 & 4 & 5 & 6 & 7 & 8 \\
\hline 1. China sales ratio 2000 & 0.089 & 0.129 & & & & & & & & \\
\hline 2. China sales ratio 1996 & 0.015 & 0.064 & 0.57 & & & & & & & \\
\hline 3. China sales growth & 0.228 & 0.705 & 0.61 & 0.32 & & & & & & \\
\hline 4. Managerial ethnic ties & 0.784 & 1.601 & 0.01 & -0.10 & 0.02 & & & & & \\
\hline 5. R\&D intensity & 0.952 & 2.061 & 0.07 & -0.02 & 0.12 & 0.20 & & & & \\
\hline 6. Product diversification & 1.803 & 0.740 & -0.26 & -0.30 & -0.14 & 0.12 & 0.01 & & & \\
\hline 7. Group size & 5905.6 & 9104.2 & -0.17 & -0.11 & -0.09 & 0.11 & 0.01 & 0.20 & & \\
\hline 8. Core industry growth & 0.124 & 0.102 & 0.12 & 0.03 & 0.18 & -0.03 & 0.26 & 0.07 & 0.04 & \\
\hline 9. Service-oriented group & 0.352 & 0.480 & -0.28 & -0.07 & 0.01 & 0.28 & -0.12 & -0.18 & 0.16 & -0.04 \\
\hline
\end{tabular}

$N=88, p<0.05$ for correlation coefficients greater than 0.21 .

Table 2

Impact of managerial ethnic ties on Taiwanese business groups' investment in China.

\begin{tabular}{|c|c|c|c|}
\hline Managerial ethnic ties & 0.015 & $(0.009)$ & \\
\hline R\&D intensity & -0.002 & $(0.007)$ & \\
\hline Product diversification & -0.060 & (0.019) & *** \\
\hline Group size & -0.006 & $(0.013)$ & \\
\hline Core industry growth & 0.189 & $(0.130)$ & \\
\hline Service-oriented group & -0.103 & $(0.029)$ & ${ }^{* * *}$ \\
\hline Constant & 0.248 & $(0.093)$ & *** \\
\hline$F$ & $3.81^{* * *}$ & & \\
\hline$R$-square & 0.22 & & \\
\hline Adjusted $R$-square & 0.16 & & \\
\hline
\end{tabular}

Dependent variable: sales of all Chinese member firms as the percentage of total group sales in 2000.

$N=88,{ }^{*} p<0.1,{ }^{* *} p<0.05,{ }^{* * *} p<0.01$ (two-tailed test).

Table 3 reports the empirical result on business groups' performance in China. Hypothesis 2 predicts that business groups with stronger managerial ethnic ties may achieve greater sales growth in China. Unexpectedly, the coefficient of managerial ethnic ties in column 1 of Table 3 is positive but is not statistically significant $(\beta=0.031, p=0.54)$. This result, together with our finding for $\mathrm{H} 1$, suggests that although managerial ethnic ties did motivate Taiwanese business groups to invest in China, they did not promise the groups' success in China.

Hypothesis 3 argues that the predicted positive effect of managerial ethnic ties on performance is negatively moderated by a group's technological capabilities. Specifically, we predict that for groups with higher technological capabilities, managerial ethnic ties yield fewer advantages. We test this prediction by including the interaction term between managerial ethnic ties and R\&D intensity in the model estimation. The result is shown in column 2 of Table 3 . As predicted, the coefficient of this interaction term is negative and significant $(\beta=-0.042, p<0.1)$, suggesting that the impact of managerial ethnic ties indeed varied with the groups' R\&D capabilities. H3 is supported. We also explore the interaction between managerial ethnic ties and R\&D capability by looking at the impact of R\&D intensity on the groups' performance in China. This impact is assessed by summing up the coefficient of R\&D intensity and that of the interaction term (between managerial ethnic ties

Table 3

Impact of managerial ethnic ties on Taiwanese business groups' performance in China.

\begin{tabular}{|c|c|c|c|c|c|c|}
\hline & (1) & & & (2) & & \\
\hline Managerial ethnic ties & 0.031 & $(0.051)$ & \multirow{12}{*}{$* * *$} & 0.064 & $(0.053)$ & \\
\hline Managerial ethnic ties ${ }^{*}$ R\&D & & & & -0.042 & $(0.023)$ & ${ }^{*}$ \\
\hline R\&D intensity & 0.034 & $(0.038)$ & & 0.139 & $(0.069)$ & ** \\
\hline Product diversification & -0.020 & $(0.111)$ & & -0.005 & $(0.110)$ & \\
\hline Group size & -0.088 & $(0.072)$ & & -0.099 & $(0.071)$ & \\
\hline Core industry growth & 1.131 & $(0.740)$ & & 0.901 & $(0.740)$ & \\
\hline Service-oriented group & 0.072 & $(0.167)$ & & 0.110 & $(0.166)$ & \\
\hline Chinasales ratio & 3.300 & $(1.190)$ & & 3.297 & $(1.173)$ & ${ }^{* * *}$ \\
\hline Constant & 0.693 & $(0.541)$ & & 0.699 & $(0.533)$ & \\
\hline$F$ & 2.23 & $* *$ & & 2.42 & $* *$ & \\
\hline$R$-square & 0.16 & & & 0.20 & & \\
\hline Adjusted $R$-square & 0.09 & & & 0.12 & & \\
\hline
\end{tabular}

Dependent variable: sales growth rate in China between 1996 and 2000.

$N=88,{ }^{*} p<0.1,{ }^{* *} p<0.05,{ }^{* * *} p<0.01$ (two-tailed test). 
and R\&D intensity). When a group has no managerial ethnic ties (thus with zero interaction term), this impact is solely determined by the coefficient of R\&D intensity, which is positive and significant $(\beta=0.139, p<0.05)$. However, having the ties reduces the positive impact of R\&D intensity. Altogether, our empirical finding supports our theoretical argument that ethnic ties may inhibit business groups with strong technological capabilities from obtaining novel and diverse information.

\section{Discussion}

While many studies have discussed firm FDI location choice and its performance from different theoretical perspectives, the particular social relationship and ethnic ties perspectives in explaining this phenomenon is limited. This study seeks a greater understanding of how firms can exploit their ethnic ties of managers in facilitating their FDI location choices and further enhance their competitive advantage after entering the market. Drawing on social network theory, using data from Taiwanese business groups, this study test the impact of ethnic ties on firm FDI location choice and performance outcome in China. Specifically, we focus on examining the condition under different firm technological capabilities which the ethnic ties of top managers can enhance firm FDI performance. This study broadens and deepens our understanding on how ethnic ties can shape firm internationalization strategies and performance in emerging markets.

Our results show that firm ethnic ties of top managers do matter in facilitating firm FDI location choice. Firms can use ethnic ties through personal networks as an informal mechanism to obtain knowledge and resources for their organization. Although kinship and community ties initially exist as affective ties and social relationships, they have the potential to serve economic and business purposes. This is particularly relevant and important when entering emerging markets where incomplete institutional supports make the liabilities of newness and foreignness more salient. The significant association between ethnic ties of top managers and Taiwanese business groups' FDI location highlight the role of ethnic ties in internationalization processes of ethnic Chinese. The findings are consistent with the Zaheer et al.'s (2009) work which indicates the important role of ethnic ties in foreign firms' location choice in India. Our study further extends Chen and Chen's (1998) work which discusses the impact of network linkages on FDI location choices by focusing on particular ethnic ties of top managers.

In contrast to expectations, our findings show that ethnic ties do not relate to post entry firm performance of FDI in emerging market. This suggests that managerial ethnic ties may be necessary but not sufficient for entrants' success in doing business in China. One plausible reason is that personal ties based on ethnicity and community links are loose networks which do not necessarily promise firms' success in FDI. Firms may still need to develop other network resources such as business linkages and non-ethnic ties to connect with different entities including suppliers, customers, competitors and local governments in order to fuel innovation and successful performance. This study also confirms and extends prior study on the association between managerial ties and performance, the micro-macro link (Luo, 2003; Peng \& Luo, 2000) to international context.

Furthermore, our results reveal that the association between ethnic ties of managers and firm performance outcomes of FDI is contingent on firm technological capabilities. The impact of ethnic ties on firm FDI performance is likely to be weaker for firm with weak technological capabilities embodied in R\&D intensity. This finding demonstrate the contingency perspective of the role of ethnic ties and identify under what circumstances ethnic ties are beneficial in firm FDI strategy. The result is in line with the social network view on the negative effect of strong ties and relationships on firm innovation (Burt, 1997). Because of redundancies in the information and knowledge being shared, these ties may not provide new insights. Firms with strong technological capabilities are more information and knowledge intensive which relies more on tacit knowledge and learning. Accordingly, strong ties may be detrimental to FDI performance for technological intensive firms because of disadvantages of social networks. Our findings support important but limited tested arguments on that social networks and connections alone are necessary but not sufficient for good performance (Liao \& Welsch, 2003). Firms with strong internal technological capabilities should focus more on exploiting these specific assets in their FDI instead of cultivating too many social networks and ties.

The findings of this study provide managers with novel insights regarding the FDI strategy and doing business in emerging markets. The findings show that ethnic ties are crucial for business success in terms of FDI location choices and performance in emerging markets. However, managers should be cautious about the limits of this kind of ties and network. Ethnic ties alone may not be enough for firm success. A successful firm also needs to have a number of firm specific assets in traditional areas such as technological and marketing capabilities. Hence, beyond a certain limit, manager's times and resources may be better spent on developing theses strategic capabilities in their internationalization than on focusing on too much networking.

\section{Limitations and further research}

The current findings should be interpreted in light of several limitations inherent in this study. First, we only focus on ethnic ties of top managers as a manager tie and social network. Future research is encouraged to explore different types of social networks such as political ties and business networks on firm FDI location choice and subsequent performance implications. Second, we only focus on the interaction effect of firm technological capabilities and ethnic ties. Future studies may investigate other internal capabilities such as marketing capabilities and their interaction with firm social networks in the internationalization processes of the firm. In terms of methodology, this study relied on data collected from Taiwanese 
business groups. Due to the limited scope, it would be overly ambitious to generalize our findings to firms from other countries. Thus, future research should consider obtaining data from other countries to validate our findings and check for consistency across country-contexts. Another limitation of this study is its cross-sectional design. In view of the practical difficulties in progressing towards longitudinal data collection on business groups and ethnic tie research, however, it seems difficult to completely remedy for this shortcoming in all future work. Finally, although we find that ethnic ties are not so much important for business groups when technological capabilities plays more significant roles, it may be worthwhile investigating how ethnic networks expand and branch out into related or unrelated sectors of activity.

\section{Conclusion}

As global competition intensifies, firm are increasingly engaging and utilizing different types of networks and relationships in order to enhance their internationalization strategy. Particularly in emerging markets like China, developing specific Guanxi and networks has been identified as the key for success. This study provides a strong theoretical and empirical foundation for understanding how ethnic Chinese networks based on kinship and community ties can provide information benefits and overcome some barriers to FDI in China. Such a role has often been suggested but not adequately accounted for in the formal theory of international business. However, the field is only beginning to develop an understanding of how ethnic networks can shape firm FDI strategy. Thus, further research is recommended in this promising area in international business.

\section{Appendix A. Appendix: Variables and operationalization}

\begin{tabular}{|c|c|c|}
\hline Variable & Operationalization & Sources \\
\hline $\begin{array}{l}\text { Tendency of a business group } \\
\text { of investing in China }\end{array}$ & $\begin{array}{l}\text { The sales of all Chinese member firms divided by } \\
\text { total group sales }\end{array}$ & Adapted from Sullivan (1994) \\
\hline $\begin{array}{l}\text { Post-entry performance of a } \\
\text { business group in China }\end{array}$ & $\begin{array}{l}\text { The sales growth rate in China over the study } \\
\text { period (i.e., the years between } 1996 \text { and 2000) }\end{array}$ & Adapted from Porter Porter (1980); Shane (1996) \\
\hline Managerial ethnic ties & Number of core managers who are mainlanders & Developed from this study \\
\hline Technological capability of a group & $\begin{array}{l}\text { Sales-weighted average of R\&D expenditures as } \\
\text { percentage of sales of the member firms }\end{array}$ & Anand and Delios (2002); Tan and Meyer (2010) \\
\hline Size of the business groups & Total employment of the business group & Tan and Meyer (2010) \\
\hline $\begin{array}{l}\text { The level of product diversification } \\
\text { of a group }\end{array}$ & The entropy measure at 1996 & Hoskisson et al. (1993); Delios and Beamish (1999) \\
\hline Core industry growth & $\begin{array}{l}\text { The sales growth of the core industry of a } \\
\text { business group }\end{array}$ & Tan and Meyer (2010) \\
\hline Service oriented groups & $\begin{array}{l}\text { A dummy equal to one if the main industry of } \\
\text { a business group belongs to a service industry }\end{array}$ & Tan and Meyer (2010) \\
\hline
\end{tabular}

\section{References}

Anand, J., \& Delios, A. (2002). Absolute and relative resources as determinants of international acquisitions. Strategic Management Journal, 23(2), 119-134. Barney, J. B. (1991). Firm resources and sustained competitive advantage. Journal of Management, 17(1), 99-121.

Björkman, I., \& Kock, S. (1995). Social relationships and business networks: The case of western companies in China. International Business Review, 4(4), 519-535. Bowen, H. P., \& Wiersema, M. F. (2005). Foreign-based competition and corporate diversification strategy. Strategic Management Journal, 26(12), 1153-1171. Buckley, P. J., Clegg, J., \& Tan, H. (2006). Cultural awareness in knowledge transfer to China - The role of guanxi and mianzi. Journal of World Business, 41(3), 275288.

Burt, R. S. (1997). The contingent value of social capital. Administrative Science Quarterly, 42(2), 339-365.

Casson, M. (1985). Transaction costs and the theory of the multinational enterprise. Houndmills: Macmillan.

Chang, S.-J., Chung, C.-N., \& Mahmood, I. P. (2006). When and how does business group affiliation promote firm innovation? A tale of two emerging economies. Organization Science, 17(5), 637-656.

Chen, H., \& Chen, T.-J. (1998). Network linkages and location choice in foreign direct investment. Journal of International Business Studies, 29(3), 445-467.

Chung, C.-N. (2001). Markets, culture and institutions: The emergence of large business groups in Taiwan, 1950-1970s. Journal of Management Studies, 38(5), 719745.

Chung, C.-N. (2006). Beyond Guanxi: Network contingencies in Taiwanese business groups. Organization Studies, 27(4), 461-489.

Cobas, J. A., \& DeOllos, I. (1989). Family ties, co-ethnic bonds, and ethnic entrepreneurship. Sociological Perspectives, 32(3), 403-411.

Dana, L. P., \& Dana, N. J. (2007). Handbook of research on ethnic minority entrepreneurship: A co-evolutionary view on resource management. Cheltenham: Edward Elgar.

Delios, A., \& Beamish, P. W. (1999). Geographic scope, product diversification, and the corporate performance of Japanese firms. Strategic Management Journal, 20(8), 711-727.

Dunning, J. H. (1998). Location and the multinational enterprise: A neglected factor? Journal of International Business Studies, 29(1), 45-66.

Eroglu, S., Thornton, C. G., \& Bellenger, D. (2005). Impact of ethnicity on management and channel building in minority enterprises. Journal of Marketing Channels, $12(3), 27-52$.

Ethnic Minority Business Forum. (2008). Minority business - making north east business inclusive. http://www.minoritybusiness.co.uk/minority/Main.nsf? OpenDatabase Accessed 30.11.08.

Filatotchev, I., Strange, R., Piesse, J., \& Lien, Y.-C. (2007). FDI by firms from newly industrialised economies in emerging markets: Corporate governance, entry mode and location. Journal of International Business Studies, 38, 556-572.

Filatotchev, I., Strange, R., Piesse, J., \& Yung-Chih, L. (2007). FDI by firms from newly industrialised economies in emerging markets: Corporate governance, entry mode and location. Journal of International Business Studies, 38(4), 556-572.

Ford, D. (2002). Understanding business marketing and purchasing: An interaction approach. Thomson Learning Emea. 
Gao, T. (2003). Ethnic Chinese networks and international investment: Evidence from inward FDI in China. Journal of Asian Economics, 14(4), 611-629.

Ghauri, P., Lutz, C., \& Tesfom, G. (2003). Using networks to solve export-marketing problems of small- and medium-sized firms from developing countries. European Journal of Marketing, 37(5/6), 728-752.

Granovetter, M. (1985). Economic action and social structure: The problem of embeddedness. The American Journal of Sociology, 91(3), 481-510.

Hennart, J. (2009). Down with MNE-centric theories! Market entry and expansion as the bundling of MNE and local assets Journal of International Business Studies, 40(9), 1432-1454.

Hoskisson, R. E., Hitt, M. A., Johnson, R. A., \& Moesel, D. D. (1993). Construct validity of an objective (entropy) categorical measure of diversification strategy. Strategic Management Journal, 14(3), 215-235.

Jones, C., Hesterly, W. S., \& Borgatti, S. P. (1997). A general theory of network governance: Exchange conditions and social mechanisms. The Academy of Management Review, 22(4), 911-945.

Khanna, T., \& Palepu, K. (2000). The future of business groups in emerging markets: Long-run evidence from Chile. Academy of Management Journal, 43(3), 268285.

Lee, D.-J., Pae, J. H., \& Wong, Y. H. (2001). A model of close business relationships in China (Guanxi). European Journal of Marketing, 35(1), 51-69.

Lee, R. P., Chen, Q., Kim, D., \& Johnson, J. L. (2008). Knowledge transfer between multinational corporations' headquarters and their subsidiaries: Influences on and implications for new product outcomes. Journal of International Marketing, 16(2), 1-31.

Liao, J., \& Welsch, H. (2003). Social capital and entrepreneurial growth aspiration: A comparison of technology- and non-technology-based nascent entrepreneurs. The Journal of High Technology Management Research, 14(1), 149-170.

Lu, J. W., \& Beamish, P. W. (2001). The internationalization and performance of SMEs. Strategic Management Journal, 22(6/7), 565-586

Luo, X., \& Chung, C.-N. (2005). Keeping it all in the family: The role of particularistic relationships in business group performance during institutional transition. Administrative Science Quarterly, 50(3), 404-439.

Luo, Y. (2003). Industrial dynamics and managerial networking in an emerging market: The case of China. Strategic Management Journal, 24(13), 1315-1327.

Mahmood, I. P., \& Mitchell, W. (2004). Two faces: Effects of business groups on innovation in emerging economies. Management Science, 50(10), 1348-13651.

Park, S. H., \& Luo, Y. (2001). Guanxi and organizational dynamics: Organizational networking in Chinese firms. Strategic Management Journal, 22(5), 455-477.

Peng, M. W. (2003). Institutional transitions and strategic choices. The Academy of Management Review, 28(2), $275-296$.

Peng, M. W., \& Luo, Y. (2000). Managerial ties and firm performance in a transition economy: The nature of a micro-macro link. Academy of Management Journal, 43(3), 486-501.

Porter, M. E. (1980). Competitive strategy: Techniques for analyzing industries and competitors. NY: Free Press.

Ruigrok, W., \& Wagner, H. (2003). Internationalization and performance: An organizational learning perspective. Management International Review, 43(1), 63-83.

Shane, S. (1996). Explaining variation in rates of entrepreneurship in the United States: 1899-1988. Journal of Management, $22(5), 747$.

Stiles, C. H., \& Galbraith, C. (Eds.). (2004). Ethnic entrepreneurship: Structure and process. Amsterdam: Elsevier JAI Press.

Strange, R., Filatotchev, I., Lien, Y.-C., \& Piesse, J. (2009). Insider control and the FDI location decision. Management International Review, 49(4), 433-454.

Sullivan, D. (1994). Measuring the degree of internationalization of a firm. Journal of International Business Studies, 25(2), 325-342.

Tan, A. C., \& Yu, T.-C. (2000). The december 1998 elections in Taiwan. Electoral Studies, 19(4), 621-628.

Tan, D., \& Meyer, K. E. (2010). Business groups' outward FDI: A managerial resources perspective. Journal of International Management, 16(2), $154-164$.

Williamson, O. E. (1975). Markets and hierarchies: Analysis and antitrust implications. NY: Free Press.

Xin, K. R., \& Pearce, J. L. (1996). Guanxi: Connections as substitutes for formal institutional support. Academy of Management Journal, 39(6), 1641-1658.

Zaheer, S., Lamin, A., \& Subramani, M. (2009). Cluster capabilities or ethnic ties location choice by foreign and domestic entrants in the services offshoring industry in India. Journal of International Business Studies, 40(6), 944-968.

Zhou, L., Wu, W.-P., \& Luo, X. (2007). Internationalization and the performance of born-global SMEs: The mediating role of social networks. Journal of International Business Studies, 38(4), 673-690. 